\title{
Reproductive behavior of White-tailed Kites (Elanus leucurus) in the Pampas of Argentina
}

\author{
Alejandro V. Baladrón ${ }^{1,2}$, Matilde Cavallii ${ }^{1}$, Matías G. Pretelli ${ }^{1} \&$ María S. Bó $^{1}$ \\ 1 Laboratorio de Vertebrados, Instituto de Investigaciones Marinas y Costeras (IIMyC), CONICET, Universidad Nacional de Mar del Plata, Mar \\ del Plata, Argentina. \\ 2 Corresponding author: abaladro@mdp.edu.ar
}

Received on 28 March 2019. Accepted on 21 August 2019.

\begin{abstract}
The White-tailed Kite (Elanus leucurus) is a raptor that has been less studied in the Neotropics than in the Nearctic region, especially in relation to its reproductive behavior. In this study, we report information about the phenology and activity patterns of this raptor at the Pampas of Argentina. We found that White-tailed Kites have a prolonged breeding season, from October to May. Time-activity budgets of mating pairs indicated a pronounced division of roles in parental care between sexes. Females devoted most of their time to nest construction, incubation and chick care (80\% of total time) and males to food provisioning and vigilance ( $70 \%$ of total time). We registered 11 cases of prey transfer from the male to the female. In four cases the transfer occurred in flight and in the remaining seven cases while individuals were perched. Our results agree with general patterns on breeding behavior of White-tailed Kites from North America, suggesting a consistent behavioral pattern throughout the species' distribution.
\end{abstract}

KEY-WORDS: breeding, parental care, raptor, sex roles, time-activity budgets.

\section{INTRODUCTION}

The White-tailed Kite (Elanus leucurus) is a mediumsized raptor widely distributed across the Americas $\left(43^{\circ} \mathrm{N}-46^{\circ} \mathrm{S}\right)$, from the southeastern United States to the Patagonia in Argentina and Chile (Figueroa et al. 2006, Thiollay 2019). This species inhabits open habitats such as wetlands, grasslands and savannas (Fjeldså \& Krabbe 1990, Dunk 1995), but it is also commonly found in modified environments such as green areas of cities and villages, agroecosystems, farmlands, and garbage dumps (Ferguson-Lees \& Christie 2001, Thiollay 2019). Kites are usually conspicuous during their foraging activities, due to their white coloration and because they search for prey performing showy flights at medium or low altitude (Mendelsohn \& Jaksic 1989, Dunk 1995).

The feeding ecology is the best known aspect of White-tailed Kite's ecology. Most studies performed along the species' distribution range agree that this kite is a specialist predator of small mammals, particularly rodents (USA: Hawbecker 1940, Bond 1942, Dixon et al. 1957, Waian \& Stendell 1970, Stendell \& Myers 1973; Chile: Meserve 1977, Schlatter et al. 1980, GonzálezAcuña et al. 2009; Argentina: Leveau et al. 2002, Sarasola et al. 2007, 2010, Baladrón et al. 2018; Brazil: Scheibler 2004). This species is characterized as an active-search predator that uses hovering as its main hunting technique (Watson 1940, Warner \& Rudd 1975, Mendelsohn \&
Jaksic 1989, Dunk 1995, Baladrón et al. 2018). The information available about reproductive behavior of the White-tailed Kite is scarce and mostly comes from North America (e.g., Hawbecker 1940 \& 1942, Watson 1940). The breeding season covers spring, summer and autumn in its northern range. This prolonged breeding season is related to the occurrence of double broods, especially in years of high food abundance (Hawbecker 1940, Dixon et al. 1957, Dunk 1995). There is little information about parental care, some authors arguing that both parents take part similarly in the incubation and nest construction activities (Watson 1940, Hawbecker 1942), while others indicate that females perform most of these tasks (Dixon et al. 1957). The male provides food to the female and chicks throughout the season (Hawbecker 1940, Watson 1940, Warner \& Rudd 1975). In its southern range, the information available on reproductive behavior is scarce and, in most cases, anecdotal (Fraga 1984, Jaksic et al. 1987), although it is estimated that the breeding season would also be prolonged in this part of kites' distribution (de la Peña 2016).

In the framework of a broader study on foraging ecology of the White-tailed Kite in the Pampas of Argentina (see Baladrón et al. 2018), we registered different activities of kites related to reproductive behavior. In this study, we compiled and analyzed the information collected during such sampling, emphasizing on reproductive phenology, parental care, and prey transfer activity. 


\section{METHODS}

The study was carried out in the southeast of Buenos Aires province, Argentina $\left(37^{\circ} 32^{\prime} \mathrm{S}-37^{\circ} 55^{\prime} \mathrm{S}\right.$; 57 $7^{\circ} 19^{\prime} \mathrm{W}-$ $57^{\circ} 30^{\prime} \mathrm{W}$ ), which belongs to the Pampas region (Cabrera 1971). The landscape in this region is dominated by grasslands, although the original community of grasses has been heavily modified by livestock grazing and agriculture (Soriano et al. 1991, Bilenca \& Miñarro 2004). The study area is characterized by its heterogeneity, including a diverse array of natural environments, such as grasslands, marshes, coastal dunes, and native woodlands, and modified environments, such as grazing fields, croplands, and urban areas (Isacch et al. 2016).

We identified the territories of two pairs of kites, from which we obtained data on phenology and behavioral patterns in different years between 2006 and 2008. One of the groups was located in a woodland area dominated by the native tree known as Tala (Celtis ehrenbergiana) in Nahuel-Rucá ranch $\left(37^{\circ} 37^{\prime} 10^{\prime \prime} S\right.$; 57 $25^{\prime} 20^{\prime \prime} \mathrm{W}$, hereafter "tala pair"). The activity of the tala pair was registered during four observation days (26 April 2006: 146 min; 27 April 2006: 279 min; 04 May 2006: 256 min; 21 October 2007: $82 \mathrm{~min}$ ). The other group was located in a periurban area (Parque Lago village; $37^{\circ} 45^{\prime} 40^{\prime \prime} \mathrm{S}$; $57^{\circ} 27^{\prime} 15^{\prime \prime} \mathrm{W}$, hereafter "periurban pair"). The activity of the periurban pair was also registered during four observation days (27 April 2007: $160 \mathrm{~min}$; 22 May 2007: $260 \mathrm{~min} ; 17$ January 2008: 88 min; 04 April 2008: 312 min). Using $10 \times 50$ binoculars, we recorded the behavior of kites individually from a fixed position (continuous recording method; Martin \& Bateson 1993, Gaibani \& Csermely 2007). From the total sampling time, we quantified only the reproductive activities of parents in the vicinity of the nest. We assigned sexes to individuals based mainly on their behavior, following the behavioral patterns reported for North America (Watson 1940, Hawbecker 1942, Dixon et al. 1957). Although the White-tailed Kite shows some sexual dimorphism (females are slightly larger and have darker backs than males; Dunk 1995), these features are of a comparative nature (Hawbecker 1942). Thus, we used external characters to differentiate sexes only when both individuals were seen together. In all cases, our assumptions of sex identification (either based on behavior or dimorphism) were positively confirmed during copulation events. All samplings were conducted under good weather conditions (no extreme wind, no rain nor fog).

We classified the activities of each individual in one of five categories: 1) vigilance: the individual watches over the nest from the air or from a perch; 2) perching: the individual remains inactive or performs maintenance activities (cleaning, grooming); 3) nest construction: the individual carries materials or builds the nest; 4) courtship: interactions between male and female related to courtship (i.e., vocalizations, material transfer, prey transfer, copulation); 5) in the nest: the individual stays in the nest; we assumed that the main behavior during this activity was incubation or chicks' care (depending on the stage of the breeding cycle). We calculated timeactivity budgets for each sex as the proportion of time that each individual devoted to each activity respect to the total time registered each day. Thus, we obtained daily budgets for each individual, and then we calculated the mean values and standard errors of each activity for each sex. In addition, we described in a detailed manner the events of prey transfer from the male to the female and quantified the time that kites employed in prey handling and consumption.

\section{RESULTS \& DISCUSSION}

In the southeastern Pampas of Argentina, the Whitetailed Kite showed a prolonged breeding season. The starting date of the breeding season was quite variable. We registered copulation events as early as 21 October (tala pair, 2007) and as late as 27 April (periurban pair, 2007). However, we also registered the tala pair making courtship displays and building the nest as late as 04 May 2006. Such delayed starting date would correspond to a second nesting attempt. Double-brooding is rare in accipitrids, however when the abundance of rodents is high and prolonged it is known that the White-tailed Kite, the Common Black-shouldered Kite (E. axillaris), and the Black-winged Kite (E. caeruleus) may raise two broods in the same breeding season (Mendelsohn 1983, Johnsgard 2009, Thiollay 2019). This behavior has also been recorded for cooperative breeders, such as Harris's Hawks (Parabuteo unicinctus), for which second brood attempts will depend on the presence of helpers at the nest (Johnsgard 2009, Thiollay 2019). The final of the breeding season was also variable. We registered fledglings in nest areas as early as 02 February (tala pair, 2007) and as late as 04 April (periurban pair, 2008). Thus, the duration of the breeding season included spring, summer and autumn, which is in accordance with previous reports from North America (Hawbecker 1940, 1942, Dixon et al. 1957).

Nests were located in the upper part of trees. The tala pair placed its nest at $-7.5 \mathrm{~m}$ of height in a tala, which was located at the edge of the woodland (Fig. 1). This nest was used by kites in previous and later years to our sampling period (A.V.B. pers. obs.). The periurban pair placed its nest at $-12 \mathrm{~m}$ of height in a Eucalyptus spp. In the same site, we registered another nest (which was abandoned early in the season) at $-4 \mathrm{~m}$ in a Pinus spp. These results agree with those from California, where this 
kite shows little selectivity in the type and height of trees used for nesting (Dixon et al. 1957).

We registered a total of $550 \mathrm{~min}$ of White-tailed Kites' reproductive activities. Mating pairs showed a pronounced division of roles in parental care between sexes, which was revealed by different activity budgets between males and females (Fig. 2). From total time devoted by kites to nest construction, approximately 98\% of time corresponded to females. Previous reports showed mixed results about the participation of sexes in nest construction. In California, for example, Watson (1940) and Hawbecker (1940) reported that both sexes build the nest, but later Dixon et al. (1957) indicated that this task is almost exclusively done by the female, which is in agreement with our results. However, since both pairs nested in previously built nests, in our study we did not record the complete process of nest construction. Many species of accipitrids use old nests, to which they add new material (Saggese $\&$ de Lucca 2001, de la Peña 2016), which may be a strategy to save time and energy at the beginning of the season (Thiollay 2019). Thus, the nest building activity that we observe was likely related to nest "maintenance", a task that is performed almost exclusively by the female in most accipitrids, although the male may bring much of the material to her (Rettig 1978, Salvador-Jr. et al. 2008, de Lucca \& Saggese 2012). In later stages of the breeding cycle, females stood guarding near or into the nest and males devoted most of their time to vigilance and prey provisioning (Fig. 2). These results indicate that incubation and direct feeding of chicks would be done almost totally by the female. On the other hand, we found that the prey provisioning was performed in total by the male, which is in agreement with previous reports for California (Watson 1940). This pattern of role partitioning between sexes, with the male being responsible for most of the hunting and the female

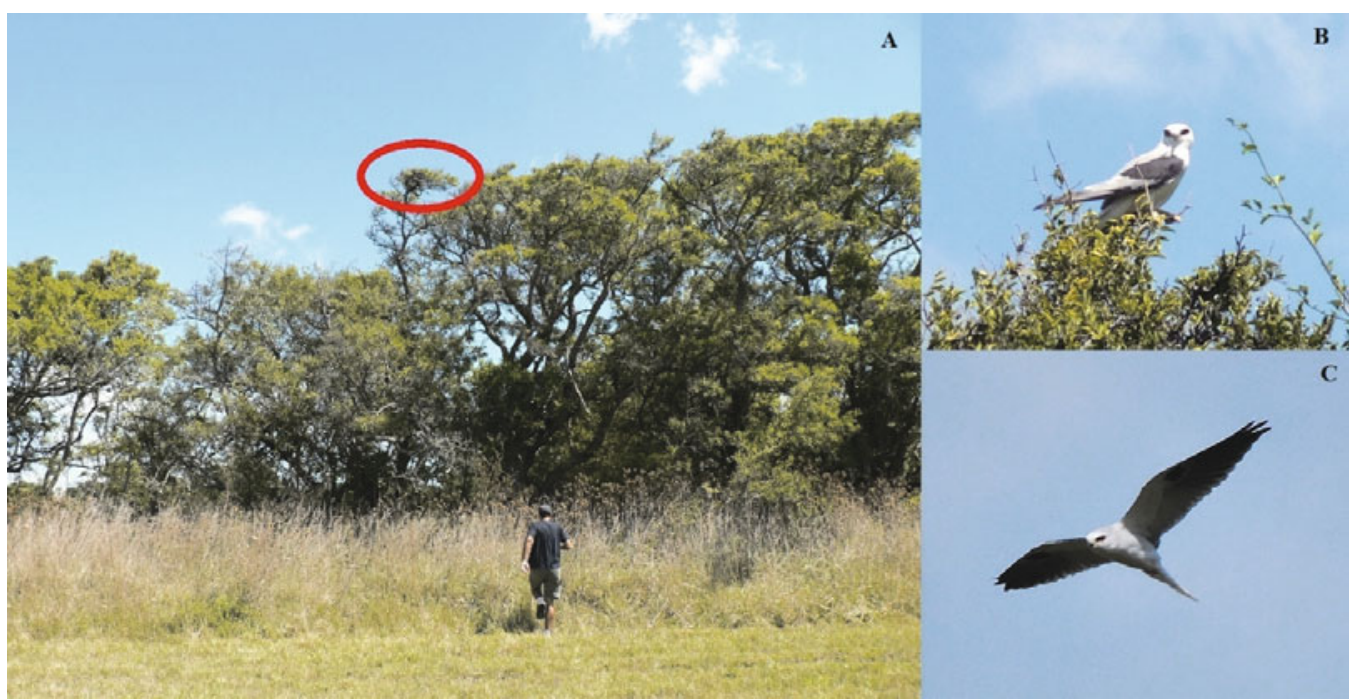

Figure 1. Location of one of the nests of White-tailed Kites (Elanus leucurus) in the upper part of a Tala (Celtis ehrenbergiana) in the edge of a Tala woodland (A). Male watching the territory perched near the nest (B) and hunting in a neighboring patch (C). Photo author: M.S.B. (A \& B); N. Chiaradia (C).

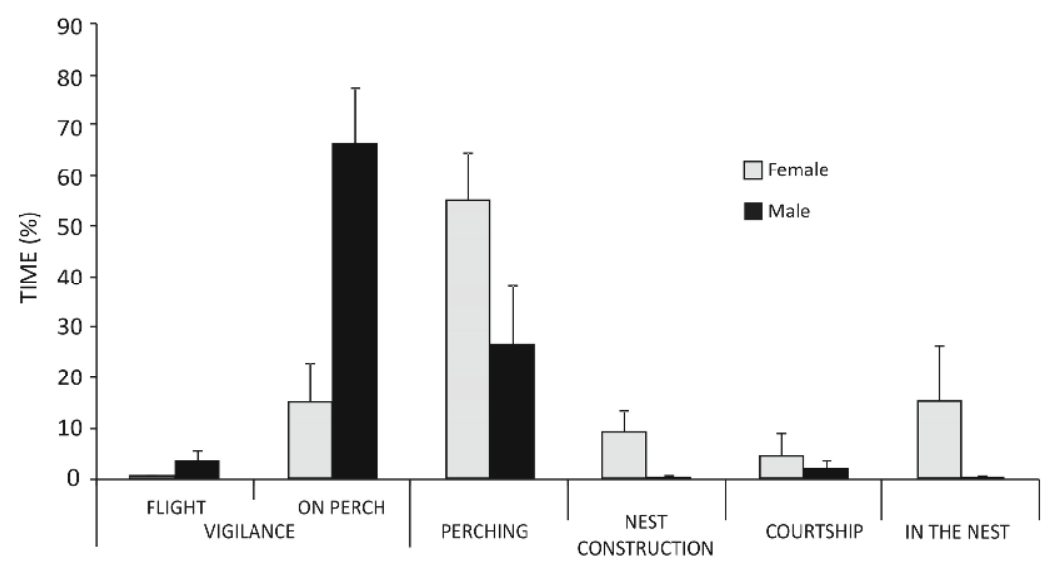

Figure 2. Time-activity budgets of male and female White-tailed Kites (Elanus leucurus) in the Pampas of Argentina. Values are expressed as percentages (mean and standard error). 
for most of the parental care in the nest (i.e., incubation, chicks care, and nest maintenance), is observed in most accipitrids, except in vultures (Newton 1979, Collopy 1984, Pavez 2001, Salvador-Jr. et al. 2008, Thiollay 2019).

We registered 11 events of prey transfer from the male to the female. All events began with the male arriving to the nest area carrying a prey in its talons and emitting whistling calls. Watson (1940) reported that the male approaches to the nesting area emitting vocalizations in order to annunciate his arriving and to coordinate the transfer. Then, the male hovered over the nesting area holding the prey with his feet downwards. We witnessed four cases of aerial transfer, in which the female leaves her perch and fluttered along the male and, when she was close enough, she positioned behind the male to take the prey with her claws. In the remaining seven cases, the transference occurred in perch. The male arrived carrying the prey and perched next to the female (or the female flies over and perched next to him), and then she took the prey from the side. Watson (1940) reported that both transfer methods were used in the same frequency by kites in California. Aerial food exchange seems to be a common practice among accipitrids, particularly harriers (Circus) and kites (Elanus). Although this behavior is clearly linked to sex role division (Watson 1977), the incidence of aerial transfer may respond to differential female requirements (e.g., hunger; Dixon et al. 1957), habitat characteristics (e.g., areas of dense vegetal cover; Watson 1977), and predation risk (e.g., for ground nesting species; Negro \& Galván 2018). More studies are needed to elucidate the biological significance of this behavior.

Frequently, after prey transfer, individuals vocalized and made courtship displays, opening the wings and moving the tail. Once the female took the prey, she briefly handled it (range $=4-38 \mathrm{~s}$ ), and lasted an average of $7.4 \mathrm{~min}$ to ate the prey (range $=1.15-16.7 \mathrm{~min}$ ). The male stay perched patrolling the area while the female was eating (7 of 11 events). In the remaining cases the male flew away and resumed foraging. After eating, the female stood in the site in five cases and flew away with the male in two cases. In the remaining four cases, she breaks twigs from the tree, and carries it to the nest in her bill. The behavior of taking twigs and build the nest in response to food transfer seems also to be usual for this species in California (Watson 1940, Dixon et al. 1957). It was frequent that, while the female was eating, she was harassed by potential cleptoparasites, especially Chimango Caracaras (Milvago chimango) and, in a lesser extent, Southern Caracaras (Caracara plancus) (Baladrón $\&$ Pretelli 2013). In most cases, intruders were chased and escorted out of the territory by the male. This agonistic relationship with caracaras may be the counterpart of that reported between kites and ravens (Corvus spp.) in North
America (Dixon et al. 1957).

Studies on raptor behavior are scarce in the literature, especially in the Neotropical region. In the case of the White-tailed Kite, there is an asymmetry between the information available for North and South America (Hawbecker 1940 \& 1942, Watson 1940, Warner \& Rudd 1975, Mendelsohn \& Jaksic 1989, Baladrón et al. 2018). Although based on sporadic records and a modest time of observation, our study show that in the Pampas the White-tailed Kite have a prolonged breeding season and show a pronounced division of roles in parental care between sexes. Our findings agree with previous reports for northern populations (Dunk 1995), and suggest a consistent behavioral pattern throughout species' distribution.

\section{ACKNOWLEDGEMENTS}

We thank owners of Nahuel-Rucá ranch for their permit for working in the ranch and to N. Chiaradia for the photo of the hunting kite. We also thank two anonymous reviewers for helpful comments on an earlier version of the manuscript. This study was funded by Universidad Nacional de Mar del Plata (EXA 545/11 grant to Laboratorio de Vertebrados) and CONICET (doctoral scholarship to A.V.B.). The field equipment was provided by Idea Wild (grant to A.V.B.).

\section{REFERENCES}

Baladrón A.V. \& Pretelli M.G. 2013. Agonistic interactions in raptors of the Pampas region. Wilson Journal of Ornithology 25: 650-655.

Baladrón A.V., Pretelli M.G., Cavalli M. \& Bó M.S. 2018. Activity budgets, foraging behavior, and diet of White-tailed Kites (Elanus leucurus) during breeding and non-breeding seasons in the Argentine Pampas. Journal of Raptor Research 52: 420-430.

Bilenca D. \& Miñarro F. 2004. Identificación de áreas valiosas de pastizal (AVPs) en las Pampas y Campos de Argentina, Uruguay y sur de Brasil. Buenos Aires: Fundación Vida Silvestre.

Bond R.M. 1942. White-tailed Kites feeding on House Mice. Condor 44: 231-232.

Cabrera A.L. 1971. Regiones fitogeográficas argentinas, p. 1-85. In: Kugler W.F. (ed.). Enciclopedia argentina de agricultura y jardinería. Buenos Aires: ACME.

Collopy M.W. 1984. Parental care and feeding ecology of Golden Eagle nestlings. Auk 101: 753-760.

de la Peña M.R. 2016. Aves argentinas: descripción, comportamiento, reproducción y distribución. Ciconiidae a Heliornithidae. Comunicaciones del Museo Provincial de Ciencias Naturales (Nueva Serie) 19: 1-436.

de Lucca E. \& Saggese M.D. 2012. Parental care and time-activity budget of a breeding pair of Black-chested Buzzard-eagles (Geranoaetus melanoleucus) in southern Patagonia, Argentina. Ornitología Colombiana 12: 17-24.

Dixon J.B., Dixon R.E. \& Dixon J.E. 1957. Natural history of the White-tailed Kite in San Diego County, California. Condor 59: 156-165. 
Dunk J.R. 1995. White-tailed Kite (Elanus leucurus). In: Poole A. (ed.). The birds of North America online. New York: Cornell Lab of Ornithology.

Ferguson-Lees J. \& Christie D.A. 2001. Raptors of the world. London: Christopher Helm.

Figueroa R.A., Corales S.S., Figueroa M.R. \& Mella A.J. 2006. The most southern records of the White-tailed Kite (Elanus leucurus) in Patagonia. Journal of Raptor Research 40: 176-177.

Fjeldså J. \& Krabbe N. 1990. Birds of the high Andes. Svendborg: Apollo Books.

Fraga R.M. 1984. Casos de nidificación otoño-invernal en algunas rapaces (Tyto alba, Asio clamator, Elanus leucurus) en Lobos, Buenos Aires. Hornero 12: 193-195.

Gaibani G. \& Csermely D. 2007. Behavioral studies, p. 117-128. In: Bird D.M. \& Bildstein K.L. (eds.). Raptor research and management techniques. Washington: Hancock House.

González-Acuña D., Briones E., Ardiles K., Valenzuela-Dellarossa G., Corales S.S. \& Figueroa R.A. 2009. Seasonal variation in the diet of the White-tailed Kite (Elanus leucurus) in a suburban area of southern Chile. Journal of Raptor Research 43: 134-141.

Hawbecker A.C. 1940. The nesting of the White-tailed Kite in southern Santa Cruz county, California. Condor 42: 106-111.

Hawbecker A.C. 1942. A life history study of the White-tailed Kite. Condor 44: 267-276.

Isacch J.P., Bó M.S., Vega L.E., Favero M., Baladrón A.V., Pretelli M.G., Stellatelli O.A., Cardoni D.A., Copello S., Block C., Cavalli M., Comparatore V.M., Mariano-Jelicich R., Biondi L.M., García G.O. \& Seco-Pon J.P. 2016. Diversidad de tetrápodos en un mosaico de ambientes del sudeste de la ecorregión pampeana como herramienta para planificar en conservación. Revista del Museo Argentino de Ciencias Naturales, Nueva Serie 18: 211-233.

Jaksic F.M., Rozzi R., Labra A. \& Jiménez J.E. 1987. The hunting behavior of Black-shouldered Kites (Elanus caeruleus leucurus) in central Chile. Condor 89: 907-911.

Johnsgard P.A. 2009. Birds of the Great Plains: Family Accipitridae (hawks, eagles, and harriers). Lincoln: University of Nebraska.

Leveau L.M., Leveau C.M. \& Pardiñas U.F.J. 2002. Dieta del Milano Blanco (Elanus leucurus) en Argentina. Ornitología Neotropical 13: 307-311.

Martin P. \& Bateson P. 1993. Measuring behavior: an introductory guide. Cambridge: Cambridge University Press.

Mendelsohn J.M. 1983. Social behavior and dispersion of the Blackshouldered Kite. Ostrich 54: 1-18.

Mendelsohn J.M. \& Jaksic F.M. 1989. Hunting behaviour of Blackshouldered Kites in the Americas, Europe, Africa and Australia. Ostrich 60: 1-12.

Meserve P.L. 1977. Food habits of a White-tailed Kite population in central Chile. Condor 79: 263-265.

Negro J.J. \& Galván I. 2018. Behavioural ecology of raptors, p. 33-
62. In: Sarasola J.H., Grande J.M. \& Negro J.J. (eds.). Birds of prey: biology and conservation in the XXI century. Basel: Springer.

Newton I. 1979. Population ecology of raptors. Vermillon: Buteo Books.

Pavez E.F. 2001. Biología reproductiva del Águila (Geranoaetus melanoleucus) en Chile central. Revista Chilena de Historia Natural 74: 687-697.

Rettig N.L. 1978. Breeding behavior of the Harpy Eagle (Harpia harpyja). Auk 95: 629-643.

Saggese M.D. \& de Lucca R.E. 2001. Biología reproductiva del Águila Mora (Geranoaetus melanoleucus) en la Patagonia sur, Argentina. Hornero 16: 77-84.

Salvador-Jr. L.F., Salim L.B., Pinheiro M.S. \& Granzinolli M.A.M. 2008. Observations of a nest of the Black-chested Buzzard-Eagle Buteo melanoleucus (Accipitridae) in a large urban center in southeast Brazil. Revista Brasileira de Ornitologia 16: 125-130.

Sarasola J.H., Santillán M.A. \& Galmes M.A. 2007. Comparison of foods habits and prey selection of the White-tailed Kite, Elanus leucurus, between natural and disturbed area in central Argentina. Studies on Neotropical Fauna and Environment 42: 85-91.

Sarasola J.H., Solaro C., Santillán M.A. \& Galmes M.A. 2010. Communal roosting behavior and winter diet of the White-tailed Kite (Elanus leucurus) in an agricultural habitat on the Argentine Pampas. Journal of Raptor Research 44: 202-207.

Scheibler D.R. 2004. Geographic variation in the size of mammalian prey taken by White-tailed Kites in the Americas. Journal of Field Ornithology 75: 218-222.

Schlatter R.P., Toro B., Yánez J.L. \& Jaksic F.M. 1980. Prey of the White-tailed Kite in central Chile and its relation to the hunting habitat. Auk 97: 186-190.

Soriano A., León R.J., Sala O.E., Lavado R.S., Deregibus V.A., Cauhépé M.A., Scaglia O.A., Velázquez C.A. \& Lemcoff J.H. 1991. Río de la Plata grasslands, p. 367-407. In: Coupland R.T. (ed.). Natural grasslands. New York: Elsevier.

Stendell R.C. \& Myers P. 1973. White-tailed Kite predation on a fluctuating vole population. Condor 75: 359-360.

Thiollay J.M. 2019. Hawks, eagles (Accipitridae). In: del Hoyo J., Elliott A., Sargatal J., Christie D.A. \& de Juana E. (eds.). Handbook of the birds of the world alive. Barcelona: Lynx Editions. https://www.hbw.com/node/52213 (Access on 05 June 2019).

Waian L.B. \& Stendell R.C. 1970. The White-tailed Kite in California with observations of the Santa Barbara population. California Fish \& Game 56: 188-198.

Warner J.S. \& Rudd R.L. 1975. Hunting by the White-tailed Kite (Elanus leucurus). Condor 76: 226-230.

Watson F.G. 1940. A behavior study of the White-tailed Kite. Condor 42: 295-304.

Watson A.D. 1977. The Hen Harrier. Berkhamsted: T. \& A.D. Poyser.

Associate Editor: Cristiano S. Azevedo. 